\title{
MANGROVES, GARBAGE, FISHING: Bringing everyday ecology to Sydney's industrial Georges River
}

\author{
Transforming Cultures eJournal, \\ Vol. 5 No 1 June 2010 \\ http://epress.lib.uts.edu.au/journals/TfC
}

\section{Heather Goodall, Allison Cadzow, Denis Byrne ${ }^{1}$}

\begin{abstract}
Post war problems of rising urban, industrial pollution and intractable waste disposal are usually considered as technical and economic problems only, solutions to which were led by experts at State level, and filtered into Australia from the ferments occurring in the United States and Britain in the 1960s and 70 s. This paper investigates the change which arose from the localities in which the impact of those effects of modern city development were occurring. In particular, this study looks at a working class, industrial area, the Georges River near Bankstown Municipality, which was severely affected by Sydney's postwar expansion. Here, action to address urgent environmental problems was initiated first at the local level, and only later were professional engineers and public health officials involved in seeking remedies. It was even later that these local experts turned from engineering strategies to environmental science, embracing the newly developed ecological analyses to craft changing approaches to local problems. This paper centres on the perspective of one local public health surveyor, employed by a local municipal council to oversee waste disposal, to identify the motives for his decisions to intervene dramatically in river health and waste disposal programs. Rather than being prompted to act by influences from higher political levels or overseas, this officer drew his motivation from careful local data collection, from local political agitation and from his own recreational knowledge of the river. It was his involvement with the living environments of the area - the ways in which he knew the river through personal and recreational experiences, which prompted him to seek out the new science and investigate emerging waste disposal technologies.
\end{abstract}

\section{Introduction}

As a young surveyor in Sydney's suburbs during the late 1950s, Kevin Howard was hoping for little more than a secure job. He felt his work at the large Bankstown Council as Health and Building Inspector would allow him to pursue a quiet life with his new family in Panania and still enjoy the fishing from small boats in the Georges

${ }^{1}$ Heather Goodall, Allison Cadzow: University of Technology, Sydney. 
River which he'd loved since his boyhood. Instead the work led him into a career as an activist which, even today, he still can't abandon. To find his voice, he first had to grapple with the urgent problems which continued to face these working class suburbs, burdened as they were with the full weight of the city's post war development.

Environmental history has been an expanding field in the last two decades, and so too has urban history. Both have produced innovative and exciting new work, yet there are some uneasy absences. The histories of the origins of environmental politics and activism in Australia tend to focus on campaigns to save rural or wilderness areas such as the Little Desert in remote western Victoria, (1968 until 1988), Lake Pedder (1972) and the Franklin River in Tasmania (1978 until 1983) or Terania Creek in northern NSW, (1979). ${ }^{2}$ These are argued to have stimulated ongoing and broader movements, particularly among city supporters. Urban histories often present themselves as 'environmental' but they seldom concern themselves with urban 'nature' in the sense of non-human species and the continuation or change of plant and animal ecosystems within city environments. More usually, urban 'environmental histories' are about industrial pollution - the chemical and toxic discharges into water, air or land fill - which damage human health. ${ }^{3}$ Or they are about the biological waste from dense human urban communities, in particular about the sewage which is so often a contaminant of rivers and coastlines, again damaging human health as well as amenity. ${ }^{4}$

Finally, where the people who act as initiators of change are considered - the activists or the thinkers who bring new ideas about environmental and human relationships to the fore - they are most often scientists who investigate agricultural problems or health concerns. Or they are the middle class urban professionals who are seeking remote,

\footnotetext{
${ }^{2}$ Robin, Libby, 1998: Defending the Little Desert: the rise of ecological consciousness in Australia, Melbourne University Press, Carlton, Vic; Mulligan, Martin and Stuart Hill 2001: Ecological pioneers: a social history of Australian ecological thought and action, Cambridge University Press, New York

${ }^{3}$ Butlin, N.G. (ed) 1976: Sydney's Environmental Amenity, 1970-1975, Australian National University Press, Canberra, and particularly Coward, Dan Huon 1976: 'From Public Health to environmental amenity, 1870-1970', Chapter 1 and Joy, C; M. Buchanan and W. Hickson 1976: 'Rivers, Bays and Ocean', chapter 6; Mayne, Alan, 1993: The imagined slum: newspaper representation in three cities, 1870-1914, Leicester University Press, Leicester; New York

${ }^{4}$ Coward, Dan Huon, 1988: Out of Sight: Sydney's Environmental History 1851 - 1981, Department of Economic History, Australian National University, Canberra ACT; Beder, Sharon, 1989: Toxic fish and sewer surfing :how deceit and collusion are destroying our great beaches, Allen \& Unwin, Sydney
} 
'pristine' wilderness places for recreation or contemplation. ${ }^{5}$ Just sometimes, they are middle class urban residents who value the aesthetic qualities of 'nature' - and who may recruit working class supporters to bring some industrial muscle to their cause of conservation. ${ }^{6}$ Only in the environmental justice movement histories do we see working class, immigrant or indigenous communities initiating action to improve their share of healthy and safe environments. But in these environmental justice accounts, there is little interest in nature, only in the way resources are moved and shared, and on how toxicity, pollution and scarcity have impacted on the living environments and health of human urban communities, rather than on the non-human ones, still less on their interaction.

This paper addresses the gaps in these accounts by opening up a discussion about both nature and society in the city. As one part of a broader study, this account is as yet only partial, drawing on the story of just one actor, Kevin Howard, in one area, the stretch of the Georges River bordered by land under the control of Bankstown Municipal Council. In this context, Howard did become a key player, rising in authority in the Council over a number of years and sitting on the committees relating not only to the Council's operation, but also to the Georges River National Park and, when it was eventually established, the State Pollution Control Board in June 1971. It was Howard's report as Bankstown Municipal Health Surveyor in 1974 which formed the principal basis for the only historical analysis of the condition of the Georges River, in Noel Butlin's benchmark study, Sydney's Environmental Amenity, 1970-1975. ${ }^{7}$ Our argument, however, is that the approach of tracing one person in BOTH his working and his recreational life will link the issues of policy, advocacy and nature as they interacted in practice, thus establishing a model for our further investigations. The new parameters of the paper are the choice of a time period so far not well investigated, from the 1960s to the 1980s; the focus on the interaction of human and non-human living species in the city; and the research question, which is to ask how and why environmental policy

\footnotetext{
${ }^{5}$ Mulligan and Hill, 2001, Ecological Pioneers; Robin, 1998 Little Desert, and Robin, Libby 2007: How a continent created a nation, UNSW Press, Sydney

${ }^{6}$ Mulligan and Hill, 2001, Ecological Pioneers; Burgmann, Meredith and Burgmann,Verity, 1998 : Green bans, red union : environmental activism and the New South Wales Builders Labourers' Federation, UNSW Press, Sydney

${ }^{7}$ Joy, C; M. Buchanan and W. Hickson 1976: 'Rivers, Bays and Ocean', chapter 6 of Butlin, (ed) 1976: Sydney's Environmental Amenity, pp 151-154, endnotes 12 and 14.
} 
change was generated. Was it at an elite level of power, that is, by central State governments or within academic research units, flowing from international precedent? Or was it generated 'on the ground', at the interface between government agency staff, local populations and the natural environments? ${ }^{8}$

The period from 1960 to 1980 covers two important processes. The first was the rising awareness in western capitalist societies that there were unexpected consequences to the post-war economic boom. One, which was evident on the Georges River, was that the multiplying new products, the planned obsolescence and the voluminous packaging of the consumption-driven 'throw-away' economy was creating mountains of garbage in cities. ${ }^{9}$ Another was that the accelerated population growth needed to provide workers for the expanding number of factories, was generating waves of human waste - urine and faeces which had to be disposed of but were expensive to transport and to treat, so the local river was an easy alternative. ${ }^{10}$ Yet another unexpected - and often unremarked - consequence of these conditions on the Georges River was a resurgent Nature. Rats, cockroaches and mangroves were just some of the opportunistic natural species for which the new conditions proved suddenly favourable, setting off still further problems for the human populations struggling already to cope with the garbage and the sewage. While rats and cockroaches could be discounted as exotic or as vermin or both, the endemic native mangroves were, as we shall see, another matter altogether. The second process was the rise of environmental sciences, and particularly of ecology, to play a prominent role in scholarly institutions and in popular understandings of environmental relationships. In the first decades after the second world war, the 1940s and 50s, mainstream and popular opinion was well reflected in the working class movement and the supportive Bankstown Council officials who campaigned to save the bush land along the river from expanding post war factory and residential development. These views were that nature conservation should be focused on native environments,

\footnotetext{
${ }^{8}$ The next steps will be to apply these parameters in archival research of local and state government records and to research the perspectives of the community groups who were involved with the environmental debates and conflicts discussed here. The community group members are readily available. The Local government archives have been largely destroyed in a fire at the Bankstown City Council Chambers, but the issues were well documented in local newspapers.

${ }^{9}$ Martin V. Melosi 2004: Garbage In The Cities: Refuse Reform and the Environment, University of Pittsburgh Press; Pittsburgh, Revised edition

${ }^{10}$ Butlin, (ed) 1976: Sydney's Environmental Amenity; Coward, 1988: Out of Sight; Beder, Sharon, 1989: Toxic fish and sewer surfing
} 
but that it should involve protection and propagation of individual native species, without consideration of where they came from. The three Native Floral gardens established in the first Georges River National Park, in existence from 1961 to 1967, are a good example. Local residents and council officers were committed to nurturing and conserving Australian native environments. To do so, they actively gathered native floral species for these gardens on motoring trips all around Australia - their goal was to conserve them by planting and propagating them in a protected environment, through which to educate local people on the beauty, importance and need to further conserve and increase native species. They, like most interested and well intentioned lay people at the time, did not feel it was necessary to pay attention to the interdependence of plants and often insects and animals in any locality, in other words, there was little awareness of the networks which make up the 'web of ecology' among endemic or local and co-habiting systems of living things. ${ }^{11}$

Ecology represented a very different approach, which focused instead on interrelationships among species, recognizing the many factors which contributed to the health of any individual species as well as the overall ecosystem of which they were an active part. Even in its early stages in the 1950s, ecological theory was changing the focus of researchers, turning attention away from individual species in isolation to the networking and interactions of the 'ecological systems' which occupied any specific area. A book published in Australia in 1954, The Distribution and Abundance of Animals, by H. G. Andrewartha and Charles Birch, ${ }^{12}$ identified four interacting factors which contributed to the prevalence of any species in a locality: resources, mates, malignities and predators, each of which then had their own contributing factors. This book gained influence overseas in the 1960s and, eventually, by the early 1970s, in

\footnotetext{
${ }^{11}$ The Floral Nursery, initially called Dalpura Floral Reserve, was situated within Fitzpatrick Park and was planned and managed from within the Georges River Trust, with strong support from the Bankstown Council and its two gardeners, the Packer brothers, who had travelled as far as Western Australia to gather seedlings. The early reports of the Trust foreground the diverse and wide-ranging origins of the native floral species within the nursery, and there is no attempt to emphasise local origins or endemism. See Georges River National Park Trust, $4^{\text {th }}$ and $5^{\text {th }}$ Annual Reports, 1965 and 1966; Georges River Parklands Trust, 8th Annual Report, 1969 (all held in Hurstville Historical Society). See also Davies, Jaquellne, Dorothy Mulholland, and Nora Pipe. 1979. West of the River Road. Towrang Publications. 1979: 41. This approach to gathering wildflowers for propagation far from their origin was particularly widespread after the Second World War, reflecting optimistic nationalism as well as expanded travel opportunities - see Timms, Peter. 2006. Australia's Quarter Acre: The Story of the Ordinary Suburban Garden. Melbourne: The Miegunyah Press: 170-190.

${ }^{12}$ University of Chicago Press
} 
Australian research institutions. The question addressed in this paper is what shifted such academic knowledge into the public domain and into the implementation of environmental policy on the ground?

\section{The First Campaign for the river: 1945 - 1960}

Kevin Howard could have expected a quiet and productive time, fulfilling his training as a surveyor with a particular interest in public health in the booming years of the late 1950s. The Georges River is a broad river flowing from the escarpments inland from Wollongong north to the Cumberland Plains and then around in an arc to Liverpool and then on to Botany Bay, threading between Bankstown, Lakemba, Lugarno and Hurstville on its northern side and Heathcote, Menai and Sylvania on its southern shore. For a hundred years it had been the site of commercial Pleasure Grounds, picnickers, boaters and swimmers. For thousands of years before that, it had been home to Aboriginal people who had used its broad productive waterways for food and transport.

But by the 1950s this river carried, particularly on its northern banks, the heaviest industrial and residential burden of modernizing Sydney's post-war boom. When Kevin Howard took up his new job, the only controls in place were nineteenth century laws governing the volume of liquids pumped into the State's rivers, not over the chemical or bacteriological composition of those liquids. There was no regulation to control the pollution pouring out of the new post-war factories or the rapidly expanding residential areas. ${ }^{13}$ The pollution levels in the river had become so high by the mid 1960s that even the Botany Bay sharks would no longer swim up to Liverpool to breed. By 1970, when the first NSW 'Clean Waters' Act was finally introduced, the Georges River had been all but destroyed.

The shift in State legislation was the result of much hard campaigning, but it has been discussed in the literature to date as if it arose largely from State government decisions based on overseas initiatives. ${ }^{14}$ As discussed earlier, the focus of analysis of the history of environmental activism has been for this period on the rural and remote debates like

\footnotetext{
${ }^{13}$ Butlin, (ed) 1976: Sydney's Environmental Amenity; Coward, 1988: Out of Sight

${ }^{14}$ See for example, Alan Gilpin 1980: Environment Policy in Australia, UQ Press, St Lucia, p 242-3; Dan Coward 1988: Out of Sight, p 269; 273.
} 
Terrania Creek and the Little Desert. Where there has been some recognition of nonState level activity and popular concern prompting the NSW Clean Waters legislation, there is no detail to indicate how it arose or who was involved, let alone why. ${ }^{15}$ Yet there had been a great deal of activity at local level, and particularly in the Georges River area. This campaigning fell into two distinct phases, the first from the 1930s on to 1960, while the second began in 1960 and continued into the 1980s. ${ }^{16}$ This paper will trace the second phase, but try to suggest both the differences between both phases as well as their underlying similarities.

The first phase was a grass-roots movement, arising from local, working class residents who had lived through the Depression as well as the 1939 to 45 war. They tried to stop the run-away postwar industrial and residential development in the Georges River area which threatened to take over the existing parks and undeveloped sandstone bushland along the river. Most of this land seemed to have been protected as 'Green Belt' in the major state planning instrument, the Cumberland County Plan of 1949. But the Green Belt definitions required local government ratification to avoid subdivision, and the lobbying of local government by real estate agents and factory developers to overturn the Green Belts began immediately the Plan was released. ${ }^{17}$ The community campaigners had all used this land informally even though most of it hadn't been gazetted as parklands, so the bush was precious to them. They were linked together by ties formed through their children's activities, through sporting and recreation clubs along the river, as well as through shared social lives in river swimming, picnicking and local music gatherings. ${ }^{18}$ In response to the very real 1950 s threats to the Green Belt, these campaigners formulated a concept of a people's National Park - based on four key principles: protection of native bushland, recognition of the importance of working class populations to 'the nation', expansion of playing areas to cater for the growing urban youth population and finally the mobilization of the power of the nation to protect all

\footnotetext{
${ }^{15}$ Dan Coward 1988: Out of Sight, p 269-270. The Senate Select Committee inquired into Water Pollution in 1968-70 and this offers some direction towards agitating groups.

${ }^{16}$ The first phase has been discussed in depth recently in 'The People's National Park: working class environmental campaigns on Sydney's urban, industrial Georges River, 1950 to 1967', forthcoming in Labour History, special section: Red, Green and In-Between.

${ }^{17}$ Winston, Denis, 1957: Sydney's Great Experiment: the progress of the Cumberland County Plan, Angus and Robertson, Sydney.

${ }^{18}$ Interviews, PPRA members; PPRA papers, held in Alf Stills' collection
} 
these. ${ }^{19}$ This campaign was at least partly successful by 1961 . While the movement had lost control of the escarpment land of one large private estate at Picnic Point, they had won a formal State gazettal of the 'Georges River National Park' over much of the river front land. Furthermore, they had won the establishment of a Georges River Trust to manage these parklands. The Trust included members of the community groups as well as members of the three Local Governments whose foreshores were enclosed in the National Park: Bankstown and Hurstville in the north and Sutherland in the south. ${ }^{20}$

This paper will trace the perspective of Kevin Howard, a key figure in the second phase campaign who became a member of the Trust during the mid 1960s as an ex officio member from Bankstown Council. ${ }^{21}$ From that time, in both the Trust and in his work on the Council, he introduced the use of evidence-based expertise to mobilize the networks of media as well as politics to win environmental protection. The directions and achievements of this second phase, including the 1970 legislation and the introduction of the newly emerging science of ecology, grew out of the work done by the first phase. Yet, as Kevin's account demonstrates, there remained little knowledge of this first wave of grass roots campaigning among its heirs in the next phase - its advocates were forgotten or ignored and their motives were misunderstood. Furthermore, the official records and media reports of the second phase give little indication even of Kevin Howard's underlying motives. A closer consideration of his perspectives and memories, however, reveals similar goals underlying both phases of the river campaigns. Such an analysis suggests also the importance not only of social, people-to-people relationships but also of human interactions with the local, natural environments in generating environmental activism.

\footnotetext{
${ }^{19}$ Davies, West of the River Road, p38.

${ }^{20}$ Leader, 8 Mar 1962; Propeller, 15 Mar 1962. Leader 3 Apr 1963; R.J.Kelly, East Hills \& Renshaw, Dpty Treasurer, Min for Lands, NSW V\&P 22 Feb 1961, v35:2555-6

${ }^{21}$ Howard, K. (1973). An Essay on Contemporary Change and Prospects of the Georges River. Diploma of Environmental Studies. Sydney, Macquarie University; Interview with Kevin Howard, 13 Feb 2006.
} 


\section{Modernity, pollution and a working class river}

To understand better the challenges which Kevin Howard faced, it is important to understand the conditions of the post-war economy in south western Sydney, where population and industry were being jammed into the Georges River suburbs in the absence of adequate infrastructure. Despite the best efforts of those who developed the Cumberland County plan, it had done little more than suggest some unattainable goals. It had assumed that orderly expansion and retention of greenspace could occur without any effective mechanisms to deliver them. In fact the rise in population far outstripped the 1949 planners' expectations.

By 1954, the increase in Sydney's population was already double what had been predicted in $1948 .^{22}$ From 1946 to 1961, it was the adjacent Bankstown and Fairfield local government areas, already densely settled, which faced the greatest absolute increase in population across the whole of Sydney, from a base of 69,599 to 232,958 people, a rise of over 160,000 people or $240 \%$. The population of Sutherland, with a much larger area on the southern side of the river, also rose steeply, adding 82,562 people to rise by $282 \%$ although with less densely packed results. While some outerlying areas like Blacktown and Hornsby had a comparable proportionate increase, their initial population was far smaller so their absolute numbers remained lower. It was only the three Georges River districts that faced such a massive rise in real numbers. ${ }^{23}$

A major weakness in the County's Plan was the lack of land zoned 'residential only' in the working class south west. Decisions for 'Residential only' zones had to be ratified at State Government level and any new, large factory developments could only be located in the areas which were not zoned 'residential only.' During the 1940s, 50s and 60s, the vast majority of the 'residential only' zones approved were in the North Shore and Eastern Suburbs, from where wealthier and higher status interest groups could exert more pressure, Proposals for 'residence only' zones for the Cooks and the Georges Rivers areas were more usually rejected. This concentrated the location of new factories into this area. ${ }^{24}$ From 1945 to 1965 , the proportion of all factories located in the inner

\footnotetext{
${ }^{22}$ Spearitt, Peter: Sydney Since the Twenties, Hale \& Iremonger, Sydney, 1978, p93, citing 1954 Census.

${ }^{23}$ Allport, 'Castles of Security', p 103. Figures from Official Year Book of NSW, No 58, p56.

${ }^{24}$ Coward 1988: Out of Sight, pp 240-42.
} 
city declined from over $68 \%$ to $32 \%$, while those in the 'South' region - predominantly Bankstown - increased from $9 \%$ to $20 \%$, an increase greater than in any other area. This led to major industrial pollution of the air and soil, as well as of the river waters themselves and a severe health hazards for local residents. ${ }^{25}$

The high number of factories in the area led the government to locate most of its new migrant worker hostels and low income city-relocation hostels into this area to provide workers for the factories. So the unpredicted increase in the population overall was compounded in the Georges River area. This in turn meant that public housing services like curbing, guttering, public transport, parkland and even public schooling, all fell far behind the rate at which people were dumped onto the hostels and estates along the river. The government's main anxiety about water, particularly after a prolonged drought from 1936 to 1942, was focused on providing adequate piped water into the thousands of new houses. So capital works of the Water Board focused on water storage and in particular dam building, which was continuous from 1918 to 1960 . There was far less focus on the disposal of liquid wastes and particularly on sewage systems. ${ }^{26}$

Although plans had been well advanced in 1911 to provide sewage across the city, the first world war, then depression and then war again had blocked any progress at all. The major disproportion in population increase and house construction along the Georges River led to the sewage infrastructure, particularly in the least affluent and so less politically influential areas, falling ever further behind the expansion of population and the extent of housing, both private and public. ${ }^{27}$ By 1959, Bankstown Municipality had the lowest rate of houses connected to a sewage system, at $31 \%$, of any major residential area in Sydney. ${ }^{28}$ This major delay led to a long backlog of sewage networking which meant that alternatives had to be found, such as continued or expanded use of septic tanks. Often however the expansion of housing into previously non-residential bushland meant that such temporary septic disposal systems were being located in unsuitable ground. This led to frequent overflows and runoff which found

\footnotetext{
${ }^{25}$ Butlin (ed) 1976: Sydney's Environmental Amenit, p 133

${ }^{26}$ Coward, Out of Sight, p 249, Butlin (ed) Sydney's Environmental Amenity, p 139.

${ }^{27}$ Coward, Out of Sight, pp 248-52.

${ }^{28}$ Ibid, p 251, figures drawn from NSW Statistical Register, cited in Metropolitan Water Sewage and Drainage Board, 1960.
} 
their way into rivers and, even more directly, to the dumping of raw or minimally treated sewage in rivers. ${ }^{29}$

By every measure the working class environments of the Georges River area came off worst - although sometimes jockeying with the Cooks River for the wooden spoon. There were more factories and so more unregulated industrial pollution. There were more and more incoming people and so there was more pressure to build houses on scarce land. This meant there was even less sewage infrastructure being built than anywhere else in the city and so the area had the worst runoff into the river. Put simply, the heaviest environmental cost of Sydney's post-war modernization was paid by the Georges River.

The laws which did exist to protect the quality of air and water had been developed in a previous era when the measure of toxicity in smoke was its colour. On this measure, clear smoke, no matter how toxic, could be poured into the atmosphere, while a factory producing black smoke might - just might - be censured. There were similarly outdated limits on what could be discharged into water, discharges being measured only in volume, not content, until 1970. There were no limits at all on the disposal of garbage. But the desire to show progress - and to find jobs for the many new residents and migrants - were the urgent priorities. Few politicians were interested in challenging the new factories to make them fall into line with what everyone recognized to be anachronistic standards. The 'Green Belt' was being dismembered to fulfill the need to service the expanding power-hungry residential areas. When the degree of industrial pollution across all Sydney rivers was finally measured in 1971, it was found that Georges River came second only to the Cooks River in toxicity level and, given its far higher population and longer length, this meant it was overwhelmingly more badly affected than any river in the city. ${ }^{30}$

These were the issues which Kevin Howard was forced to confront as a young Council officer from 1960. He was not then aware of the long history of Aboriginal use of the

\footnotetext{
${ }^{29}$ Ibid.

${ }^{30}$ Coward, 1988: Out of Sight, pp 245-52; Butlin (ed) 1976: Sydney's Environmental Amenity, pp 140-49, 176-183 demonstrates both the disproportionate historical pressure on the Georges River and that it had continued until this survey in the early 1970s.
} 
river, displayed in archeological sites including middens, camps and tool making sites, all demonstrating use by many Aboriginal people at any one time as they shared in the river's rich resources. This highly social Aboriginal presence on the river was echoed by white Australian settlers' $19^{\text {th }}$ century use of the river's extensive bushland foreshores, land which was then both public and privately owned. Both had been used for very public recreation, criss-crossed by informal tracks for fishing, hunting and gathering. Public recreation was also focused on the commercial 'Pleasure Grounds' which attracted literally thousands of urban visitors at weekends from the 1880 s to the 1930s in large rowing, sporting, dancing and bushwalking groups. ${ }^{31}$ The 1930 s and 1940s river residents who had developed the first phase of the environmental campaign to save the river's 'Green Belt' bushland had themselves used the river as the centre of their social activities. They had continued actively using the undeveloped escarpments but had also formed many groups, like rowing, football and music clubs, and gathered regularly for informal fishing, picnics and swimming all through summer in the river bathing enclosures. These highly valued social networks led directly into the environmental activism of spokespeople like George Jacobsen and Alf Stills for groups like the Picnic Point Regatta Association, which had spearheaded the campaign for a National Park to save the foreshores in the 1950s.

\section{Mangroves and garbage}

The challenge which had not confronted the earlier riverside campaigners when they shaped their demands had been the mounting piles of garbage with which local government authorities were faced. In the shift to a consumption driven economy, all of the waste from the houses and factories poured out uncontrolled, and much of it ended up in the Georges River. As a council health officer, Kevin Howard's early encounters with mangroves were as a 'problem' which occurred in the context of trying to work out what to do with these mountains of garbage. At first his junior role at the Council meant he was implementing little more than the first guesses of his bewildered more senior

\footnotetext{
${ }^{31}$ Glennys Barhnam 2003, Riverside Reflections: memories of Lugarno, self published; Rosen, S. 1996. Bankstown: a sense of identity Sydney, Hale \& Iremonger; Molloy, Andrew 2004: The History of Padstow, Australian Media, Sydney; Molloy, Andrew 2006: The History of Panania, Picnic Point and East Hills, University Publishing Services, University of Sydney; Earnshaw, Beverly 2001: The Land Between Two River Chapter 6; McLoughlin, Lynne, 1985a: The Middle Lane Cove River: a history and a future, Centre for Environmental and Urban Studies Macquarie University (Sydney)
} 
council colleagues at what to do. In tune with the community anxiety about youth and the need to provide organized recreation in a crowded area, the Council set about 'reclaiming' all the land it called 'waste' which meant in practice the uneven land or wetlands along parts of the water's edge. A mark of the 'uselessness' of such places was invariably the presence of mangroves. The dispensability of mangroves is illustrated in Kevin's recollection of a proposal for a Council garbage tip ${ }^{32}$ at the upper limit of Little Salt Pan [Reilly's] Creek:

The Little Salt Pan tip arose out of a thought that we were running out of tipping space .... One of my colleagues at the Council was looking after tips and his idea was to cut down the mangroves at the back of Padstow and do the filling job down there. They had playing fields they wanted to put in. ......... See it wasn't just a matter of 'let's get rid of a few more mangroves', it was: 'what are we going to do with the rubbish? We've got nowhere else to go with it!'

On the assumption that land on which mangroves grew was unwanted and useless, or indeed was an example of the failure of 'nature' to function in the variable conditions of tidal inundation, public officials often presented their projects as beneficial not only to people but also to the environment. The Engineer at Hurstville Council, for example, reported in 1968, in relation to Lime Kiln Bay: 'The mangroves in this location are quite a new development'. ${ }^{33}$ The following year, he revealed his attitude to the plants in his report on their 'tremendous increase':

'It is tragic to see the waterways silting to this extent and anything that can rid the river of these unsightly mudflats and foul mangrove swamps should be applauded by everyone, 34

In the same year, he was again quoted widely as describing mangroves in the Hurstville riverfront areas as 'a noxious weed and a cancerous growth'. ${ }^{35}$ The Hurstville Engineer was referring obliquely to the persistent circulation of theories of illness in which 'swamps', 'miasmas' and 'mists' were thought to cause respiratory illnesses. Despite being long discarded by the medical profession, the $19^{\text {th }}$ century association of 'swamps', 'miasmas' and illnesses

\footnotetext{
32 These places were uniformly referred to as 'the tip' and trips to 'the tip' with parents and family formed a large part of childhood leisure in the 1960s. They may also now be known as a 'dump'.

${ }^{33}$ Dunstun, 1990: 'Some Early Environmental Problems in NSW Estuaries' p3, citing Shire Engineer in Hurstville Municipal Council [HSC] Minutes 5 Sept 1968.

${ }^{34}$ Ibid, citing HSC Minutes, 6 Mar 1969, p1.

${ }^{35}$ Ibid.
} 
remained entrenched in the popular imagination and was frequently raised in discussions around mangroves. ${ }^{36}$

Filling such 'wasted' places with society's waste in the form of garbage seemed only fitting, a win-win situation in which both the imagined dry land and a healthy, wastefree and clean society would be 'reclaimed' by digging out mangroves. Vincent Durick, ALP State member for Lakemba argued in 1964 that the provision of playing fields would greatly enhance the future for the low cost housing being built in the Housing Commission area of Herne Bay:

In my own area at the present time there is a section of wasteland which consists for the most part of mangrove swamps. It forms the upper section of Salt Pan Creek.... It is estimated that by controlled tipping of household refuse $1,250,000$ cubic yards of rubbish will be disposed of. If this plan comes to fruition... it will have a three-fold result. First it will overcome the problems of some metropolitan councils with regard to garbage disposal, which have become urgent... Second, it will result in the reclamation of an area which is at present wasteland and an eyesore..... it is at the present only swamp land... Third it will result in the provision of spacious playing fields. ${ }^{37}$

A further association of mangroves with harm and antisocial behaviour was the use of the plants and their removal as punishment for council workers who were defying authority. Kevin explained how the Council had chosen the staff who would assist with the work being undertaken to assist the Georges River Trust to 'reclaim' the land round Fitzpatrick Park:

.....they were blokes who weren't working out too good in the garbage service....

so they'd give them an axe and say "Go down there and chop a few mangroves out, that'll sort you blokes out." So that was the way we treated some of the garbos when they got a bit obstreperous....

The garbage problem was a threat to the mangroves but, ironically, the debate exposed some of the sources for the contempt for the plant and the environment it created.

There has since been careful work done to analyse the annual Defense Department aerial photographs begun in 1930, to show the changing relationship between mangroves and salt

\footnotetext{
${ }^{36}$ Carlo M. Cipolla, 1992: Miasmas and Disease: Public Health and Environment in the Pre-Industrial Age (New Haven, CT: Yale University Press); S.N. Tesh, 1995: 'Miasma and 'Social Factors' in Disease Causality: Lessons from the Nineteenth Century.,' J Health Politics, Policy and Law 20, no. 4; Goodall, Heather, 2006: 'Frankenstein, Triffids and Mangroves: anxiety and changing urban ecologies' in Australian Folklore, 21, pp 82-98

${ }^{37}$ VP Durick, ALP, MLA Lakemba, 21 Oct 1964, NSW V\&P v 54:1522
} 
marsh in the Georges River. ${ }^{38}$ This shows that the mangrove expansion has been concentrated in the tributaries and bays rather than the main river, which not only has a stronger tidal flow but has suffered from the underwater erosion caused by dredging. Even in these bays and tributaries, the expansion of the mangroves has varied substantially in its direction. In Lime Kiln Bay, Little Salt Pan [Reilly's] Creek and other areas the mangroves had advanced landward, at the expense of the saltmarsh. On Salt Pan Creek itself, the mangroves had advanced both landwards, cutting into the salt marsh, but also seaward, filling in the open water on greatly increased silt mud flats. The open water visible from the air decreased from 50\% in 1930 to only $22 \%$ in 1970 . This has been because Salt Pan Creek is alone in this group in having a source which is beyond the sandstone, arising as it does in the fertile and much cleared shale areas. This has meant that it has its own uniquely heavy silt burden derived from clearing on its upper reaches in the shale soils. The other areas like Little Salt Pan and Lime Kiln Bay are essentially inlets from the estuary, with no major freshwater source flowing in from the shale to deliver silt which might counterbalance the underwater erosion being caused by the dredging at their mouth or in the centre of the inlet itself. $^{39}$

Because the Council staff had been poring over these aerial maps, Kevin was aware of the exponential expansion of the mangroves. But he began to have doubts about the strategies his colleagues were proposing, In particular he began to fear that the everexpanding piles of garbage would consume more and more of the riverbank. He was spurred on in this by the angry resident response to the Little Salt Pan and Salt Pan Creek ideas for tips, in which local groups organized a vocal campaign to oppose the dumping plans. ${ }^{40} \mathrm{He}$ began to propose an alternative which took up less area by dumping more intensively, which would create higher and higher mounds of garbage instead of extending laterally. He met conflicts among Council staff, but his awareness of the rising pressure from resident action groups, and his own increasing seniority, allowed him to push through with the plan to increase the height of Milperra tip. With few other options available at the time, this seemed to offer at least a partial solution.

\footnotetext{
${ }^{38}$ Robert J. Haworth 1995: 'Bush Tracks and Bush Blocks: The Aerial Photographic Record from SouthWest Sydney, 1930 - 1950' ' ANZ Journal of Person-Environment Studies, 49: 32-42, p37-8

${ }^{39} \mathrm{Ibid}$; Adam, P. 1998: 'Mangroves and saltmarsh communities', in Atwell, B.J., Kriedemann, P.E. and Turnbull, C.G.N. (eds.) Plants in Action. Adaptation in nature, performance in cultivation. Macmillan, Melbourne, pp.563-564.

${ }^{40}$ Howard, 1973.
} 
Kevin had a particular reason as Health Inspector to be concerned about what was being discharged into the water. The garbage dumps were an important part of this problem. A study in 1972 found that leaching from putrescible (that is liquid and rotting) garbage was making its way at an alarming rate into Sydney's waterways. But three of the four most smelly and dangerous dumps were on the Georges River at Liverpool, Salt Pan Creek and Mill Creek, all flowing into the stretch of the river managed by the Bankstown Municipality. ${ }^{41}$ However even more worrying for the area's residents was the most easily identified contaminant which was $e$. coli, the bacteria in sewage. Even recently, it has been possible to write as if virtually all of Sydney's sewage was being piped effectively to ocean outfalls by the $1920 \mathrm{~s} .{ }^{42}$ In reality, much of the northern bank of the Georges River remained unsewered by 1940s and human waste was disposed of via a fragile combination of domestic septic tanks and sanitary pans (the latter collected and delivered to sewage farms like that at Liverpool which was already overloaded and subject to breakdown during heavy rain at which time untreated sewage flowed directly into the river). ${ }^{43}$ There was a sewage farm and sanitary collection works at Peakhurst, between Salt Pan Creek and Lime Kiln Bay. ${ }^{44}$ The wartime construction of military bases, military hospitals and internment camps at Herne Bay and Holsworthy was all done without adequate sewage disposal being constructed at all. The postwar conversion then expansion of these facilities into migrant hostels and housing commission residential areas just compounded the problem and in 1962 all these Commonwealth and State settlement areas were pouring what was largely untreated sewage into the Georges River. Unlike the garbage tips which led to the uprooting of mangroves, the sewage contamination meant far higher nutrients in the water which offered a more favourable habitat to stimulate mangrove expansion. ${ }^{45}$

\footnotetext{
${ }^{41}$ D.J. Dwyer and Associates, 1972: Report on the Disposal of Solid Wastes for the Metropolitan Waste Disposal Authority, Sydney, cited in M. Buchanan: 'Dumping on Land', Chapter 10 of Butlin (ed) Sydney's Environmental Amenity, 1970-1975, ANU Press, pp 264-5.

${ }^{42}$ Beder, Sharon 1989: Toxic fish and sewer surfing: how deceit and collusion are destroying our great beaches, Sydney : Allen \& Unwin; Beder, Sharon 1990: "The Sydney Experience." In Sydney's Strangled Sewerage System, edited by A. M. Cooke. Sydney: ANZAAS.

${ }^{43}$ Coward,. 1988: Out of Sight, pp 240-42; Butlin, (ed) 1976: Sydney's Environmental Amenity, p 133

44 Interviews with Robert Haworth, Ellen James.

${ }^{45}$ McLoughlin, L. 1987: Mangroves and grass swamps: Changes in shoreline vegetation of the middle Lane Cove River, Sydney, 1780's-1980's. Wetlands (Australia), 7 (1): 13-24; McLoughlin, L, 1985b: 'Mangroves in perspective', Proceedings of the First International Marinas Conference, Macquarie. University, 1985. Graduate School of the Environment, Macquarie University; McLoughlin, L, 2000: Shaping Sydney Harbour: sedimentation, dredging and reclamation 1788-1990s, Australian Geographer 31 (2) 183-208.
} 
But while it might be good for mangroves, there was no question that e.coli were bad for people. Kevin Howard was alarmed enough to be collecting samples in the early 1960s, sending them to the Government Analyst, Ernest Ogg, and urging State government intervention.

\section{Closing the River}

Of even greater concern to Kevin Howard, however, was what was being dumped into the rivers by the proliferating factories, a concern that had begun to be shared by those of the Picnic Point river campaigners, like George Jacobsen, who were familiar with factory work . Kevin had particular suspicions about a number of factories upstream along the main river but also those at the head of Salt Pan Creek. Their discharges were harder to track and to deal with than sewage, as Kevin explained:

.... in the early ' 60 's we were aware of these huge, huge outfalls, you know big pipes like that running three quarters full, with sewerage just pouring out, day in and day out, from the treatment works ... because it wasn't just the sewerage, human sewerage is really easy to deal with, you can turn it back in to drinking water real easy. But it was that huge ICI up in Villawood, all through the war years had been pouring the worst kind of chemicals into the creeks up there which found their way back into the Georges River. And Yates, the fertilizer factory was the same. And then there was a battery company and another called Lane's Chemicals up there on Salt Pan ... There were a number of companies that were producing very, very dangerous chemicals. ...

....We were trying to prosecute people but that just wasn't possible. ... The government analyst' $d$ say "Well you got to give us a clue what we're looking for because you know there could be anything here, ten thousand different chemicals". ... There was a chemical company there on Canterbury Road. All I'd know was, every now and again there'd be dead fish all over Salt Pan Creek. And we had a system that if it was Salt Pan Creek, say, in the upper reaches, the chances are it's this chemical company, so we'd send people to rush out and take samples, to give to the government analyst ..... But furthermore, it took maybe two days for it to get down to the water, then two or three days to mix into Salt Pan Creek so we were already five days behind the game. But those complex chemical industries, they were making pesticides and herbicides, they were really bad news and there were others, they were doing terrible things and they had been doing them for a very, very long time. ${ }^{46}$

Kevin Howard and others in the council were deeply worried about what they could see pouring into the river but they had been frustrated by the inadequacy of their legal power to act against the companies and government bodies causing the contamination.

${ }^{46}$ Howard, Interview, 2006. 
In April 1962 they decided to use their data to take the unprecedented step of closing the river's six bathing enclosures to any public swimming. They expected that this would cause such a public outcry that the government would be forced to act to strengthen the laws. ${ }^{47}$

It is a measure of the divergent approaches of the older, Picnic Point Regatta Association methods and those of the newer professionals like Kevin Howard that although they both appealed to the same ALP politicians, like the Local Member Joe Kelly, they related to community groups in very different ways. Alf Stills and George Jacobsen expected to contact and talk with their fellow committee members around football games and cricket fundraisers, as well as to harass the politicians by phone or face to face. ${ }^{48}$ Kevin expected to consult with his fellow council officers and to follow up his emerging contacts with scientific researchers like those in Ogg's department, meanwhile waiting to see what the community groups did. The consolidating bureaucracies of modern administration were shifting the locus and strategies of environmental activism away from the community and into the corridors of governmental offices.

As Kevin recalled it:

We made this little change in the early '60's when we were aware of these huge, huge outfalls, you know big pipes like that running three quarters full, with sewerage just pouring out, day in and day out, from the treatment works. The thought was that we'll never get anywhere with that sort of level of pollution.

Because it wasn't just the sewerage. Human sewerage is really easy to deal with, you can turn it back in to drinking water real easy. But it was the huge chemical company up in Villawood, all through the war years had been pouring the worst kind of chemicals into the creeks up there which found their way back into the Georges River. And fertilizer factory was the same. I was saying, 'there's no way we're going to get anywhere while ever that happens', so our agreed program was to get rid of the continuous sewerage outfalls - the treated sewerage - into the river. So that started my boss, before me, in getting these tests run and we established that there was gross pollution, primarily after rain. Now we thought we had a king hit in our bag: 'We'll close the rivers!' Of course there were six swimming baths down here, schools were going down for sports days to swim at the baths. If you go down to Woollies there's pictures on

\footnotetext{
47 St George Leader, 5 Apr 1962

${ }^{48}$ Interviews with Alf and Eileen Stills, and with George Jacobsen's familiy; Correspondence and reports in PPRA papers, Alf Stills Collection.
} 
the side of Woollies of the East Hills Life Saving Club, marching along the beach with their flags. Well, we closed the rivers!

In the aftermath of the dramatic announcement of the river closure in 1962, Kevin waited for community outcry. It didn’t come.

And you know there wasn't a single letter in the paper, there wasn't a single telephone call to the council.

Kevin was aware of older Picnic Point campaigners at that stage, both as local personalities and as members of the newly formed Georges River Trust. But he had made no contact with the local activist networks, so he wasn't able to prepare or nurture the grass roots movement which might have eventuated, a failure of grass roots organizing on which he later reflected with regret. ${ }^{49}$

Here am I, thinking 'This is going to cause a furore, the politicians are going to feel the hot breath of society here!' - and not a soul was interested.

That was one of the really sobering lessons I learnt about community reaction. So you really had to, first of all get the community wound up, it wasn't getting the politicians wound up, you got to get the community wound up first, get them all wired then start your program. So then I realized I had to be on an environmental awareness thing.

It was also the case, however, that in the intervening decade the children of the working class river campaigners had grown up. In 1952 the river had been the only place to cool off in the summer heat waves and it had as well provided essential places for socializing and for friendly - and romantic - interactions. But by 1962, for a new generation of children the focus for swimming had shifted from the murky East Hills river baths, with the smelly jelly blubbers hanging dead on the wire mesh with the retreating tide, to the sparkling blue chlorinated waters of the new Bankstown Olympic Pool, where the swimming stars John and Ilse Konrad trained and where parents could be assured that skilled lifeguards watched constantly over their children's safety and their morals! Closing the river meant very different things in 1962, and affected far fewer people than it might have done in 1952.

The absence of a community outcry about the rivers frustrated Kevin, confirming his belief that suburban communities hadn't taken a leading role in environmental activism so far and weren't likely to do so in the future. He made very few inquiries about the community base of the Trust because he assumed it had been initiated by the Municipal

${ }^{49}$ Interview 13 Feb 2006 
Councils and State government politicians. Being from a younger generation from further downstream, Kevin Howard knew virtually nothing about the grass roots basis of the PPRA nor about its years of tenacious campaigning. So easily did the history of the community activism in which George Jacobsen, Alf and Eileen Still and all the others had taken part simply disappear from view.

The Government Analyst, Ernest Ogg released his report in June 1962, confirming Howard's dramatic decision. Ogg concluded that the Georges River was a menace to health. ${ }^{50}$ He pointed mainly to the huge volume of sewage being discharged directly into the river, although he expressed concern at other results of population build up and poor planning, like contamination from household sullage. His warnings about industrial pollution were less acknowledged in public responses. The report was largely used as a way to fuel the calls for the redress of the severe lag in the promised connections to sewer transport systems in this area. This was so even though this would simply have moved the problem from inland river to ocean outfall and would not have addressed the urgent problem of the poor existing river water quality. Joe Kelly, State ALP Member for East Hills, for example, focused on the urgent need for piped sewage removal to restore a healthy environment in which people could swim, but at the same time he still managed to blame the mangroves for pollution when he complained that riverside tips received 'no cleansing effect from tidal movement because of the swampy nature of the area with its many mangroves'. 51

Kevin Howard kept on agitating within the council by mobilizing scientific evidence. For example, he encouraged a geomorphologist from Sydney University to send students to work on changing river structures. ${ }^{52}$ He took a more active role in the regulatory bodies, looking eventually to bodies like the State Pollution Control Commission to tackle the problems, rather than the grass roots movements, although he did strengthen his contacts with the emerging groups. Howard was particularly active in contacting the media to build up pressure for effective legal pollution controls. He welcomed the activism of the Padstow Heights residents when the Salt Pan Creek tip

\footnotetext{
${ }^{50}$ St George Leader, undated photocopy but internal dating indicates 1962, held in Hurstville Local Studies Collection.

${ }^{51}$ NSW V\&P 9 October 1962, v 42:822

${ }^{52}$ Howard interview, 13 Feb 2006.
} 
was proposed and he was able to use it to bolster his strategy to sabotage the plan, although he did not stimulate this local activism directly nor take part in it. Instead, he escalated his media work, informing and briefing reporters at the local and metropolitan papers. Eventually, he won the interest of the ABC TV producers of Four Corners, which allowed him to work with the media in ways which had not seemed conceivable to Alf Still and George Jacobsen only a decade before. Howard was able to direct the $\mathrm{ABC}$ reporters to local activists for interviews and send their cameramen to film the pipes pouring effluent into the river. ${ }^{53}$ As he recalls this battle:

The pollution laws were old local government laws that said you know you can't put buckets of blood in the river and if you do it's a two pound fine kind of thing, so I was an activist. I think that's where I ended up starting with the State Pollution Control Commission, because there was no legislation that affected pollution. There was just some crazy little ordinance that said, you know, you're not all allowed to emit smoke greater than so much on a scale where there were squares that were drawn up that came in different grades of black, and so forth. For black smoke you were fined two pounds and if it was clear smoke it was okay. It might have been sulphur dioxide in great quantities - but because it wasn't black it was okay.

So the pollution laws were literally non existent and, and you know, part of my activism, I ended up convincing Four Corners to do a program about that and about the major pollution that we had here in Salt Pan Creek. Which is still there to today, it's all still there on the bed of the river. It's not dioxins, like Parramatta River, but it's principally lead and other contaminates such as pesticides which are still in Salt Pan Creek.

It flowed from the companies, some of them are still here but some of the companies are long since gone. But that battery place on Fairford Road was the principle generator of lead and acid. It just flowed straight into the river.

Their back fence finished at the high tide line and it was just pouring out. Oh, it made wonderful television! $!^{54}$

The media coverage Kevin and others generated contributed to the building public pressure which led the State government to change the laws governing water pollution in its new Clean Waters Act 1970. But the implementation of the Act was so weak that it led to widespread disappointment.

\footnotetext{
${ }^{53}$ Despite extensive searching of ABC archives, this episode of Four Corners has not been located.

${ }^{54}$ Kevin Howard interview, 13 Feb 2006
} 
It was Howard's frustration in experiences like this of trying to force real change which led him to undertake scientific studies himself, resulting in his report of 1973. As he put it in 2006:

'The environmental impact issue is something which drove me to do the course at Macquarie University on environmental studies. ${ }^{, 55}$

He undertook a formal postgraduate degree in environmental science, which he turned to the purpose of addressing the problems of the river. ${ }^{56}$ The local conditions and the conflicts over them had impelled Kevin Howard to bring the new science of ecology into both his professional work and his activism.

\section{Fish and fishing with mates}

Aside from their differing styles of politics, there was another, perhaps more important difference between Howard and the earlier Picnic Point river campaigners. This lay in their differing personal activities and so their differing ways of knowing the environment.

There had been few anglers among the PPRA members, most of whom had been preoccupied with rowing or on land-based shoreline conservation. ${ }^{57}$ The final element in Kevin's motivation for activism was his passion for fishing, which made him conscious of another whole dimension of river change, one which yet again had a relationship to the deteriorating health of the river and a relationship to the state of its mangroves. The site of this change was the river bed, which had been reshaped irreparably by two processes. One was siltation resulting from the clearing of land on the upper rivers, including not only the upper freshwater Georges and O'Hare's Rivers on the southern coastal escarpments but the long Salt Pan Creek, which flowed as a freshwater river all the way down from the agricultural shale soils of Bankstown into the George's River itself.

\footnotetext{
55 Ibid.

${ }^{56}$ Howard 1973, leading to his 1974 Report of the Municipal Health Surveyor, Bankstown Municipal Council, 26 March, 1974, the report cited by Joy, Buchanan and Hickson in Butlin (ed), 1976, Sydney's Environmental Amenity, p151-4.

${ }^{57}$ PPRA papers. Interviews with PPRA members.
} 
The other damaging process was dredging, carried on at great profit to supply sand for the voracious home building industry but undertaken also for all those complex underlying beliefs about needing to keep rivers 'clean' and pure. Ironically, dredging had been critically important for the Picnic Point Regatta Association and it became so for the Georges River Parklands Trust. It was only the royalties from dredging which had allowed the PPRA then the Trust to fund their improvements program, despite support given by the council. As a fisherman, however, Kevin Howard saw the issue differently. He saw it in terms of the bream and whiting whose movements through their established habitats he had come to know intimately over the years:

I always used to fish at the junction of Little Salt Pan Creek and the Georges River, probably from the time I was ten. The spot's still there to this day but the configuration of the bottom isn't!

We knew where the bank was and if you threw in the right spot, your line went along and dropped over the edge of the bank and the fish used to swim along, this is all under water. So it was a pretty good spot. Once we came to live here, it became a more serious occupation because there were neighbours here. We used to watch the tide charts and every second Friday night, it was always a good time, you always wanted the run in tide at certain hours and so it was a very regular affair.

But it was right where this bloke was dredging.

And then he took the whole bank out, so the bottom became just - flat - so there was no more feature that the fish would be interested in following. It really got me fired up. I had a really good spot and he buggered it up.

Being keen fishermen I was anxious because I could see in those early stages that the river was deteriorating. And that sort of started me off, fired me up on a program that ended up being a bit of an activist I suppose you could say. The Trust was actually one of the bad guys in my equation in the sense that they were dredging, or they were supporting the dredging and getting the royalties from the dredging. And it was changing the geomorphology of the river, very substantially. The Park Trust were good in that they were providing a wonderful amenity which has endured to this day, and will continue to endure, but their activities, in those early days, I thought, weren't all that clever. ${ }^{58}$

Dredging scoured out the sand at the centre of the river beds, so as a consequence it ate away the beach near the edges, making it fall away from the land more steeply,

\footnotetext{
${ }^{58}$ Howard interview, 13 Feb 2006
} 
therefore lessening the ledge area available for silt carried by the river to settle on and for mangroves to advance across. Dredging certainly counteracted some of the physical effect of silting. But what Kevin was seeing was the distortion of underwater topography by the dredging process and as a fisherman he understood the impact that had on fish habitats and the fish's preferred movements.

Just as important for him, it undermined the sociality he enjoyed so much as he relaxed with his neighbours. For those who didn't fish, such as the campaigners from Picnic Point Regatta Association, the impacts of dredging were invisible and seemed to be of less immediate consequence than the chemicals and filth being poured into the river from factories and hostels.

\section{Historical ecology: reflections}

Kevin Howard's is just one man's story, and there are many other perspectives on those times. Howard was, however, in a key position, not only in his formal roles as Council officer and participant in the Georges River Trust and the State Pollution Control Board. He was also actively involved in calling in media and political interest, feeding out information and directing attention to the most blatant - and readily photographed examples of his concerns. At the very least, his perspective on events can suggest some key questions to be pursued more deeply.

His story is firstly an example of how emerging scientific approaches made their appearance, and had their impact, on the river. Along with the overall local environment, the older Picnic Point campaigners had focused on individual species, seeking to conserve either particular native flowers or birds, even if they were not endemic to the area. Howard, on the other hand, recognized the interconnectedness of the ecological systems of the river and its shores. He was supportive of increasing the accessibility of parklands for local, working class residents, but he was much more alert than most of the older campaigners had been to the cascading effect on whole ecosystems from the disturbances of development. Yet Kevin Howard did not learn the scientific approaches to ecology first and then use them to notice problems in the local environment. On the contrary, it was his local observations and those of the people around him, along with their varied strategies to intervene in the damage they saw being 
done, which led him to seek out science as a tool for raising awareness. It was local expertise, the local recognition of problems, which only then led to the search for scientific tools for solutions, not the other way round.

Secondly, rather than any unified State response to problems emerging in the post-war development, Howard's account indicates the tensions within and between the State agencies. At local government level, there were differences of opinion about how to tackle problems, while Howard's ambivalent relationship with the State Pollution Control Board suggests the uneasy interactions of local councils and state bodies. And Howard quite consciously relayed information into the halls of State Parliament, seeking local politicians' interest in the environmental problems he could see and mobilizing the media to shift parliamentary votes. So there was no single 'State' strategy to manage either specific environmental problems or the overall development issues of the post-war period. If anything, Howard's observations demonstrate the failure of state planning strategies to predict or cope with escalating population pressures, while the massive expansion of garbage appears to have been completely unexpected, with the solutions being made up - and disputed - as the council officers tried out one option after another. And the wheels of government response turned very slowly - the factories had been pouring out pollutants for at least 20 years before the antiquated pollution controls were addressed at all with new legislation. So Howard's 'insiders' view of the State apparatus shows a bureaucracy often in confusion, invariably in conflict and certainly without a coherent plan.

What is definitely a difference between the two phases of the environmental movement on the river, between the grass roots community campaign of the 1950s and the more networked, professional and bureaucratic campaign in which Kevin Howard was involved, was the role of the media in shifting popular and political opinion. While George Jacobsen and Alf Stills had lobbied their elected ALP State Member, and ALP representatives on the local council, they had had very little direct input into local newspaper coverage. It was only in Kevin Howard's time, in the 1960s and particularly the 1970s, that first local newspapers and then television became the focus of activist attention, to be cultivated, coaxed and used for all they were worth in winning votes for change. While there were scattered items in the media about the first campaign and its win of the National Park in 1961, these tended to be factual 'news' items. By the time 
Kevin Howard was campaigning, the 'extended analysis' piece was the goal. For Howard, this culminating in the Four Corners report which used film to tell the story, as well as interviews with local resident action groups to whom, this time, Kevin Howard had done the introductions. Howard aimed to give politicians, like Pat Rogan who succeeded Joe Kelly (the long time local ALP member for East Hills) a vehicle for regular media attention. As Kevin remembered it:

I was closely aligned to Pat Rogan, the local member, who had taken over from Joe Kelly and was looking for a peg to hang his political hat on. The pollution of the river was that peg. And it turned out to be not just a one-off thing with Pat, he was always very good. I used to fire him up and give him information and press releases and that sort of thing. It was all fair and above board - I was never contrary to what the council was doing it. We were all very open and there was nothing clandestine about it. The council had a very good rapport with Pat Rogan and vice versa.

This strategy of managing media along with political relationships was very different from the tools available to the 1950 s community organizers.

The final issue raised by Kevin's story is the close relationship between human and non- human species on this river in the course of its environmental history. The interventions made by the Georges River Trust and the Council - in their 'reclamation' of the swamps and mangrove-bearing shorelines - and the anxieties within their own ranks about their impacts - the George Jacobsens and the Kevin Howards - were all complicated by the actual behaviour of the mangroves themselves. The plant species were endemic, having interacted and competed with salt marshes and other vegetation species see-sawing movements up and down the bank, depending on minute sea-level changes to alter the salinity of the soil, or on the numbers of grazers like swamp wallaby at any one time, which was in turn dependent on the number of human hunters, and so on. In the rapidly changing conditions of post-war development, the mangroves were not passive victims. Instead, they had responded to the heavy siltation and rising nutrient levels of the river, as well as the damage done to salt marshes by encroaching buildings, by becoming invasive. This in turn activated the complex body of popular mythologies held by surrounding human populations, about illnesses, about swamps, about dark twisted forests, smelly swamps and 'wasted' land. Empirically verifiable observations of rapid mangrove expansion intersected with irrational fears and deeply held antagonisms towards these recalcitrant, aggressive and seemingly hostile plants, to make them appear as an enemy of health, hygiene and modernity. Only the people like 
Jacobsen and Howard, who saw the mangroves as part of wider, interconnecting networks, were uneasy with the 'reclamation' work. In Howard's case he began, despite puzzled opposition, to launch an active search for alternatives in the struggle between disposal of garbage and destruction of mangroves and their environments.

The interactions of fish with changing environments was even more powerful in motivating Kevin Howard to address environmental damage which, in the case of the changes in the river bed due to dredging, most people could not even see. Howard was himself aware of the changed shape of the river bed not because he himself had seen it, but because he knew the habits of the fish he had been catching since his boyhood. He knew - from the distance of the surface - what types of river bed topography the bream, whiting and other species were seeking. So he could tell when it had been lost, not because it was visible on the surface but because the fish behaviour had changed. So it was the fish which had motivated Howard to try to make the river bed changes publicly visible by organizing a small amount of council funds for that university geomorphologist and their student projects. Trying to make people - or television cameras - actually see the river bed changes was a tool in Howard's struggle to increase the awareness of the interconnected changes in the environment which, ultimately, affected the humans as much as the fish.

Despite their differences and lack of contact, the two phases of environmental activism in the Georges River shared a fundamental well-spring for their advocacy, which was in their roots in the sociality of their interactions with nature on the river. The working class campaigners of the 1950s had deeply personal but collective engagements in their experiences of the river lands, whether it was around the netted pool or on the football training fields or stumping around the mangroves and the swamps. Kevin Howard was not only searching for a means to make working class urban life less destructive, but for a way to regain that sociality with his neighbours which he valued so highly in their regular fishing expeditions. These had been times when, whatever their daily lives, they pooled their efforts to know the tides, to observe and learn the fishes' preferred movements and habits, to understand how the shape of the riverbed created that desired habitat and to predict the fishes' movements so as to be able to fish the river together. 
It is, then, an irony that the shift to protecting mangroves and allowing them to flourish has largely depopulated the riverbanks. Salt Pan Creek, for instance, is now deeply lined with what can only be called a mangroves forest, There is no possibility now of the prawning, fishing or swimming which were so marked a part of the sociality of the Creek for much of the $19^{\text {th }}$ and $20^{\text {th }}$ centuries... and for many centuries before that if we consider the Aboriginal sociality on these river of which the middens, hearths and other archaeological traces are evidence. The river and the riverbanks have become less a zone of social engagement except in the designated and authorized parklands. The river and its banks now risk being available only for a distanced, aestheticised observer role, whether in the consumerist 'gaze' of a saleable house 'view' or for a conservationist appreciation. This means the parks are even more precious than they were in the past when all of the sandstone frontages were available in de facto commons. But it raises an urgent question about whether the river bank can now be cared for as a whole. Are large sections of it being increasingly abandoned, in effect, to become a depopulated and imaginary 'pristine' mangrove wilderness which has not existed in reality within the thousands of years of human memory on the river?

Today's Georges River ecological advocates concerned about wetland and riverbank environments now face a number of new challenges. These include the escalating use of power boats and jet skis which result in severe bank erosion. They also include the rising levels of freshwater run off and continuing threats of development encroachment from the south. The most difficult challenge, however, might yet prove to be how to restore sociality to the river to allow its historical ecology to continue. 


\section{Acknowledgements}

The authors have greatly appreciated the generous assistance of Keith V. Smith, the participants in discussion around an earlier presentation of this work: Joe Powell, Barry Higman, Lorenzo Veracini, Emily O'Gorman and Peter Read, and particularly, Robert Haworth. We have benefited greatly from editorial advice by Hilary Yerbury and the comments of two anonymous reviewers. Most importantly, the authors wish to thank the key interviewee, Kevin Howard for his interest and enthusiasm for the research and for his ongoing commitment to the river.

\section{Interviewees:}

Pat Forbes

Robert Haworth

Kevin Howard

Carol, Col and Kevin Jacobsen

Ellen James (nee Williams) and Frank James

Ruth Staples

Alf and Eileen Still

Shayne Williams 


\section{Bibliography}

Adam, P, 1998: 'Mangroves and saltmarsh communities', in Atwell, B.J., Kriedemann, P.E. and Turnbull, C.G.N. (eds.) Plants in Action. Adaptation in nature, performance in cultivation. Macmillan, Melbourne, pp.563-564.

Allport, Carolyn, 1987: 'Castles of Security: The New South Wales Housing Commission and Home Ownership 1941-1961', pp 95-124 in Max Kelly (ed) Sydney: City of Suburbs, UNSW Press in association with the Sydney History Group

Andrewartha, H.G. and Charles Birch, 1954: The Distribution and Abundance of Animals, University of Chicago Press, Chicago.

Barhnam, Glennys, 2003: Riverside Reflections: memories of Lugarno, self published, Sydney.

Beder, Sharon, 1989: Toxic fish and sewer surfing :how deceit and collusion are destroying our great beaches, Allen \& Unwin, Sydney

Buchanan, M. 1976: 'Dumping on Land', chapter 10 of Butlin, N.G. (ed) 1976: Sydney's Environmental Amenity, 1970-1975, Australian National University Press, Canberra

Burgmann, Meredith and Burgmann,Verity, 1998: Green bans, red union : environmental activism and the New South Wales Builders Labourers' Federation, UNSW Press, Sydney

Butlin, N.G. (ed) 1976: Sydney's Environmental Amenity, 1970-1975, Australian National University Press, Canberra

Cipolla, Carlo M, 1992: Miasmas and Disease: Public Health and Environment in the Pre-Industrial Age, Yale University Press, New Haven, CT

Coward, Dan Huon 1976: 'From Public Health to environmental amenity, 1870-1970', Chapter 1 of Butlin, N.G. (ed) 1976: Sydney's Environmental Amenity, 19701975, Australian National University Press, Canberra

Coward, Dan Huon, 1988: Out of Sight: Sydney's Environmental History 1851 - 1981, Department of Economic History, Australian National University, Canberra ACT

Davies, Jaquellne, Dorothy Mulholland, and Nora Pipe. 1979. West of the River Road. Towrang Publications.

Doyle,T.J. 2000: Green power: the environment movement in Australia, UNSW Press, Sydney

Dovers, Stephen 2000: Environment, history and policy: still settling Australia, 2000, 306, Oxford University Press, Melbourne

Dovers, Stephen1994: Australian environmental history: essays and cases, Oxford University Press, Melbourne

Dwyer, D.J. and Associates, 1972: Report on the Disposal of Solid Wastes for the Metropolitan Waste Disposal Authority, Sydney, cited in M. Buchanan:

'Dumping on Land', Chapter 10 of Butlin (ed) Sydney's Environmental Amenity 
Earnshaw, Beverly 2001: The Land Between Two River : the St George district in Federation times, Kogarah Historical Society, Kogarah, Sydney

Gilpin, Alan 1980: Environment Policy in Australia, UQ Press, St Lucia

Goodall, Heather, 2006: 'Frankenstein, Triffids and Mangroves: anxiety and changing urban ecologies' in Australian Folklore, 21, pp 82-98

Haworth, Robert J. 1995: 'Bush Tracks and Bush Blocks: The Aerial Photographic Record from South-West Sydney, 1930 - 1950' ' ANZ Journal of PersonEnvironment Studies, 49: 32-42

Howard, K. (1973). An Essay on Contemporary Change and Prospects of the Georges River. Diploma of Environmental Studies. Sydney, Macquarie University

Howes, Michael 2005: Politics and the environment : risk and the role of government and industry, Allen \& Unwin, Crows Nest, N.S.W.

Hutton, Drew and Libby Connors, 1999: A history of the Australian environment movement, Cambridge University Press, Cambridge; Melbourne

Joy, C; M. Buchanan and W. Hickson 1976: 'Rivers, Bays and Ocean', chapter 6 of Butlin, N.G. (ed) 1976: Sydney's Environmental Amenity, 1970-1975, Australian National University Press, Canberra

McLoughlin, Lynne, 1985a: The Middle Lane Cove River: a history and a future, Centre for Environmental and Urban Studies Macquarie University, Sydney.

McLoughlin, L., 1985b: 'Mangroves in perspective', Proceedings of the First International Marinas Conference, Macquarie. University. 1985. Graduate School of the Environment, Macquarie University

McLoughlin, L., 1987: Mangroves and grass swamps: Changes in shoreline vegetation of the middle

Lane Cove River, Sydney, 1780's-1980's. Wetlands (Australia), 7 (1): 13-24

McLoughlin, L., 2000: 'Shaping Sydney Harbour: sedimentation, dredging and reclamation 1788-1990s', Australian Geographer 31 (2) 183-208.

Martin V. Melosi 2004: Garbage In The Cities: Refuse Reform and the Environment

University of Pittsburgh Press; Pittsburgh, Revised edition

Mayne, Alan, 1993: The imagined slum: newspaper representation in three cities, 18701914, Leicester University Press, Leicester; New York

Molloy, Andrew 2004: The History of Padstow, Australian Media, Sydney

Molloy, Andrew, 2005: The History of Panania, Picnic Point and East Hills, University Publishing Services, University of Sydney

Mulligan, Martin and Stuart Hill 2001: Ecological pioneers: a social history of Australian ecological thought and action, Cambridge University Press, New York

Papadakis,Elim, 1996: Environmental politics and institutional change, Cambridge Universtiy Press, Cambridge; Melbourne

Robin, Libby, 1998: Defending the Little Desert :the rise of ecological consciousness in Australia, Melbourne University Press, Carlton, Vic. 
Robin, Libby 2007: How a continent created a nation, UNSW Press, Sydney

Rosen, S, 1996: Bankstown: a sense of identity, Hale \& Iremonger. Sydney,

Spearitt, Peter, 1978: Sydney Since the Twenties, Hale \& Iremonger, Sydney.

Tesh, S.N. 1995: 'Miasma and 'Social Factors' in Disease Causality: Lessons from the Nineteenth Century.,' J Health Politics, Policy and Law 20, no. 4

Timms, Peter. 2006. Australia's Quarter Acre: The Story of the Ordinary Suburban Garden. Melbourne: The Miegunyah Press

Winston, Denis, 1957: Sydney's Great Experiment: the progress of the Cumberland County Plan, Angus and Robertson, Sydney 